\title{
Impact of climate and diseases on pea yields: what perspectives with climate change?
}

\author{
Maud Bénézit ${ }^{1}$, Véronique Biarnès ${ }^{2}$ and Marie-Hélène Jeuffroy ${ }^{3, *}$ \\ ${ }^{1}$ INRA, UMR Agronomie INRA-AgroParisTech, Bâtiment EGER, Campus AgroParisTech, 78850 Thiverval-Grignon, France \\ 2 Terres Inovia, Avenue Lucien Bretignières, Campus de Grignon, 78850 Thiverval-Grignon, France \\ ${ }^{3}$ UMR Agronomie INRA-AgroParisTech-Université Paris-Saclay, Batiment EGER, 78850 Thiverval-Grignon, France
}

Received 28 November 2016 - Accepted 21 December 2016

\begin{abstract}
For farmers, pea crop is characterized by a large yield variability between years, between areas, and even between fields in a same small area in a given year. In dry year, spring pea crops are mostly affected by water stress and high temperature but significant yield losses can also be caused by a root disease, Aphanomyces euteiches, particularly during wet years. Winter pea can escape partially from drought, high temperature, and root disease during the reproductive phase of the crop cycle. However, when winters are mild, without progressive negative temperatures, which provide frost acclimation, available cultivars are not resistant enough to frost and are susceptible to aerial diseases such as ascochyta blight and bacterial blight (Pseudomonas syringae pv. pisi), thus leading to yield losses. A better adaptation of sowing dates, an improvement of lodging resistance and a limitation of the sowing density can limit the development of ascochyta blight for winter pea crops. For spring pea, an increased use of Aphanomyces soil test could avoid to sow the crop in infested fields. Current spring pea varieties are the result of changes in plant architecture including the reduction of 1000-seed weight that have led to yield losses by increasing the fragility of variety facing these stresses. The development of a pea crop model, simulating the effect of various stress encountered on winter and spring pea crops, can help to better define the regions adapted for the production of these two types of cultivars, and also help the breeders to better define and choose which trait to improve in order to increase the pea productivity and yield stability. National and European projects are in course to breed new varieties more adapted to different stresses.
\end{abstract}

Keywords: pea / yield / crop model / abiotic factors / climate change

Résumé - Impact du climat et des maladies sur les rendements du pois : quelles perspectives avec le changement climatique? Le pois est une culture connue pour son rendement irrégulier. Une grande variabilité des rendements est en effet souvent observée entre années, entre régions et même sur une année à l'échelle d'une petite région. En année sèche, le stress hydrique et les fortes températures sont des stress fréquents en pois de printemps et en année humide, des pertes de rendement importantes peuvent être causées par Aphanomyces euteiches. Le pois d'hiver peut échapper en partie aux stress de fin de cycle et à $A$. euteiches mais lorsque les hivers sont doux, sans températures négatives progressives pour développer un bon endurcissement, il devient plus sensible au gel et aux maladies telles que l'ascochytose ou la bactériose. Une meilleure adaptation des dates de semis, une amélioration de la résistance à la verse et une limitation de la densité au semis peut permettre de limiter le développement de l'ascochytose en pois d'hiver. En pois de printemps, une meilleure mise en œuvre de test pour détecter Aphanomyces pourrait permettre d'éviter de le semer en parcelle contaminée. Les modifications d'architecture des variétés, notamment la réduction du poids de mille grains ont pu les fragiliser par rapport à différents stress. Une augmentation du poids de mille grains pourrait peut-être amener un progrès. La mise au point de modèle de culture sur le pois intégrant l'effet de différents stress, rencontrés sur pois d'hiver et pois de printemps, pourra aider à mieux définir les zones de production pour ces deux types de culture et aider la sélection à définir les critères importants à améliorer pour augmenter leur productivité et la stabilité du rendement. Des projets engagés à l'échelle nationale et européenne pourraient conduire à la création de variétés mieux adaptées à différents stress.

Mots clés : pois / rendement / modèle de culture / facteurs abiotiques / changement climatique

\footnotetext{
* Correspondence: marie-helene.jeuffroy@inra.fr
} 


\section{Introduction}

Climate change is a reality. Since several decades, significant change in aerial temperature, cumulative rainfall, and distribution over the year have been measured in most of the French regions. The climatic data analysis during the last 50 years has shown an abrupt shift of these variables at the end of the 1980s (Brulebois et al., 2015). After the 1987/88 year, in the Paris Basin, an increase (i) of the average temperature, during winter and summer, (ii) of the number of days with high temperature $\left(T_{\max }>25^{\circ} \mathrm{C}\right.$ for example), and (iii) of the maximum temperature during summer was observed. But no change in the incident global radiation was measured. The number of days with frost, during winter, was also lower after this shift, and the cumulative minimum temperatures lower than $0{ }^{\circ} \mathrm{C}$ also decreased.

Grain legumes grown in France are particularly sensitive to climatic stress. Biological nitrogen fixation, specific to legumes, is highly sensitive to numerous abiotic factors, as water stress, water logging, a lack of oxygen in the soil linked, for example, to a compacted soil (either in the sowing bed or the ploughed layer), or even to a deficient $\mathrm{P}$ or $\mathrm{K}$ nutrition (Voisin and Gastal, 2015). Physiological processes, involved in crop growth and in seed number production, are also sensitive to water stress (Lecoeur and Sinclair, 1996; Guilioni et al., 2003), to high maximal temperatures (Jeuffroy et al., 1990), and to winter frost (Lejeune-Hénaut et al., 2008).

Besides its direct effect, weather has also indirect impacts on yield, through its effect on biotic stress. The occurrence and detrimental effects of diseases, either of the aerial or root parts of the plants, were responsible of low yields in recent years.

For pea, breeding led to the current availability of three types of cultivar: spring varieties, winter 'classical' varieties, and winter cultivars highly reactive to photoperiod (called $\mathrm{Hr}$ ). The sowing date of the Hr cultivars may be realised in the early autumn without high risk of frost, contrarily to the classical winter peas. Breeding of $\mathrm{Hr}$ cultivars is recent and these cultivars are not yet grown by farmers. The geographical distribution of cultivar types across France was, until recent years, mainly related to climate (with spring peas in the North and winter peas in the South), but the recent availability of highly frost-resistant winter cultivars changed this distribution. Today, half of the winter pea areas are in the half North of France, while spring cultivars are grown in the South-West and Middle-West of France. Given the future climate change, a change in these geographical areas should occur, and even be enhanced, in order to decrease the occurrence and impacts of climatic stress on yield.

Legumes are known as key crops to enhance sustainability of cropping systems (Voisin and Gastal, 2015; Schneider et al., 2015). The strong decrease of their areas, in the last 30 years, was mainly explained by their lower annual competitiveness compared to the major crops like wheat or rapeseed which have been enhanced by the dominant French sociotechnical system (Meynard et al., 2013; Magrini et al., 2016). Their future re-introduction in the French cropping systems will partly depend on their ability to face climate change. How should we prepare this evolution? How should we adapt the pea crop? We propose such an analysis in this paper.

\section{Change in pea yield and areas in past years: the effect of climatic factors}

\subsection{Change in pea yield and areas}

During the past thirty years, yield evolution at the national scale shows first a constant increase from 1983 to 1999 , with a mean rate of around $+0.6 \mathrm{q} / \mathrm{ha} / \mathrm{year}$, and a sharp decline thereafter, marked by a larger variability between years: the mean deviation from the trend shows a twofold increase compared to the first phase (Fig. 1). The same trend was observed concerning the evolution of the cultivated areas of pea, with a small lag time compared to yield evolution. While cultivated areas rapidly increased from 1983 until 1993, reaching more than 700000 ha at the end of the period, they sharply decreased afterwards, with small recent positive variations, mainly due to public policy incentives (Fig. 1).

While winter cultivars only represented less than $5 \%$ of the French pea areas until mid-90s, they represented $25 \%$ of the pea areas in 2015 (estimate from the CAP declaration). The area increase in winter peas reached more than $1000 \mathrm{ha} / \mathrm{year}$, while the total pea area loss was in average $28000 \mathrm{ha} / \mathrm{year}$. Thus, the change observed in national pea yield is mainly due to the variability of spring pea yields.

\subsection{Influence of climatic factors on national pea yield}

The pea crop is known to be highly sensitive to climatic conditions during its crop cycle. More precisely, pea yields are influenced by drought and high temperatures during the period of grain formation, as shown by Guilioni et al. (2003). Thus the analysis of the average yield per year may be analyzed with two main climatic indicators characterizing water stress and cumulated maximal temperatures exceeding $25^{\circ} \mathrm{C}$, as shown for one main department in France (Fig. 2).

The highest national mean yield was reached in 1999. This year was characterized by a very favorable climate with regular rainfall and mild temperatures during the whole pea crop cycle and especially in June in the north of France during the flowering and the seed filling periods of spring peas (Quoi de Neuf, 1999; Fig. 2). On the contrary, the lowest mean yields of the last 15 years occurred on years 2001, 2007, 2011, and 2015. In the north of France, these years were characterized by a long period of drought during various phases of the pea crop cycle and this can explain such low results. In 2001, rainfall in March delayed the sowing period during the first fortnight of April. This late sowing delayed the reproductive period (flowering and seed filling) to a period of time of high water stress. In 2007, the climate was very dry from sowing date to flowering (no or very few rainfall during the two months after sowing) and this early drought led to a yield reduction despite the fact that rainfall was normal during flowering. The year 2011 was a very warm and dry year: low rainfall during spring, leading to a great drought from sowing to the end of the pea crop cycle. Finally, in 2015, the climate was also dry in May and June, and high temperatures occurred at the end of the cycle. In 2005 and 2006, about 2 weeks with maximal temperatures above $25^{\circ} \mathrm{C}$ during flowering or seed-filling period had also a great impact on pea yield (Jeuffroy et al., 2015). 


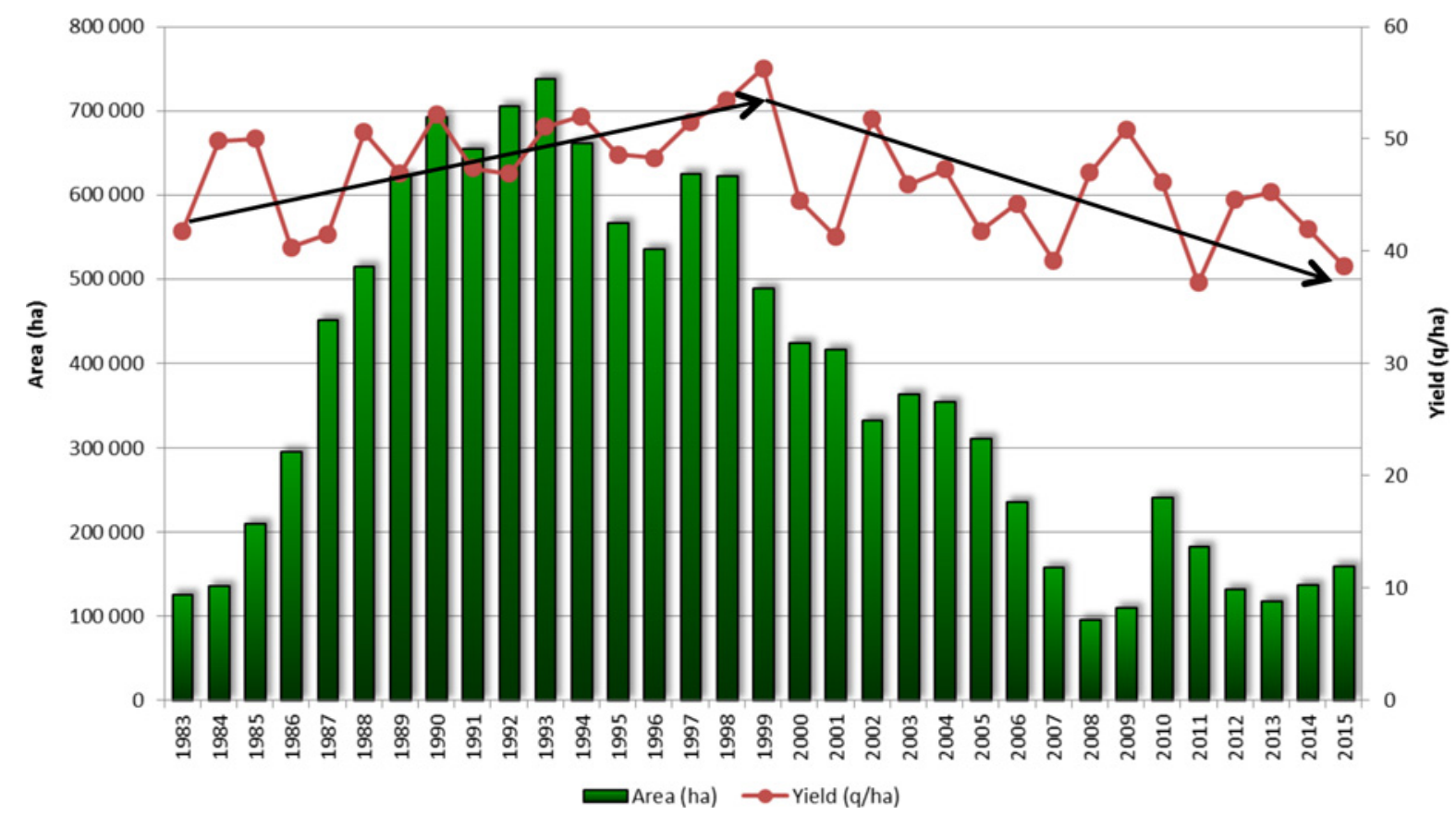

Fig. 1. Evolution of yields and cultivated areas for pea from 1983 to 2015 (from UNIP until 2014, and Agreste in 2015).

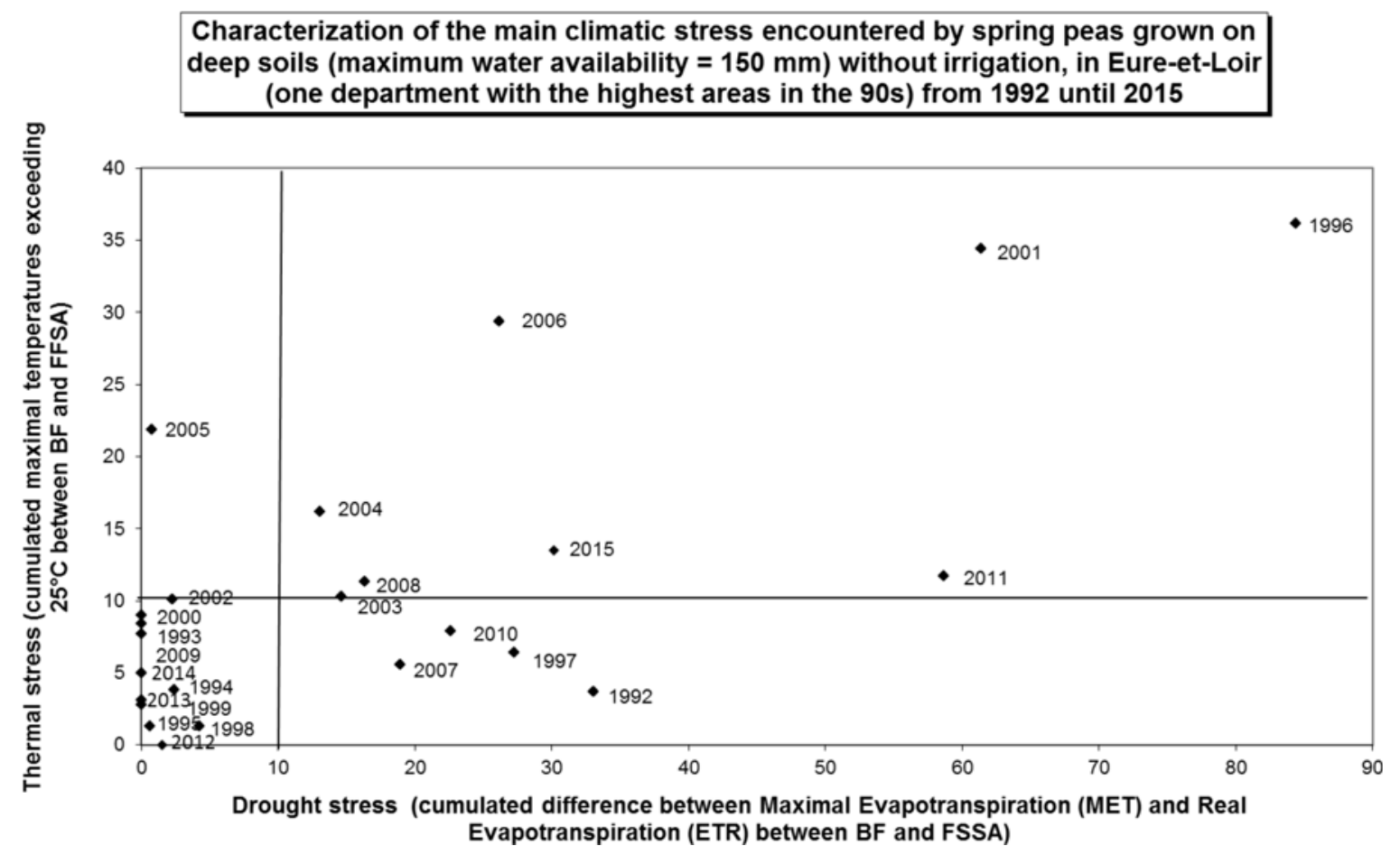

Fig. 2. Characterization of the main climatic stress encountered by spring peas grown on deep soils (maximum water availability $=150 \mathrm{~mm}$ ) without irrigation, in Eure-et-Loir (one department with the highest areas in the 90s) from 1992 until 2015: drought stress (cumulated difference between Maximal Evapotranspiration (MET) and Real Evapotranspiration (ETR) between beginning of flowering (BF) and final stage in seed abortion (FSSA), and thermal stress (cumulated maximal temperatures exceeding $25^{\circ} \mathrm{C}$ between BF and FSSA).

\subsection{Transfer of pea crops to dryer areas}

The decrease of the cultivated areas of pea from 2000 onwards was concomitant with a transfer shift of the remaining areas to regions with lower potential yields (Fig. 3). In the last few years, more than $50 \%$ of the French pea crop areas were located in these intermediate zones, while they represented less than $20 \%$ in the early 80 s. These areas are characterized by shallow soils with lower water storage capacity thus resulting in lower yields than in the North zone, which used to be 
a.

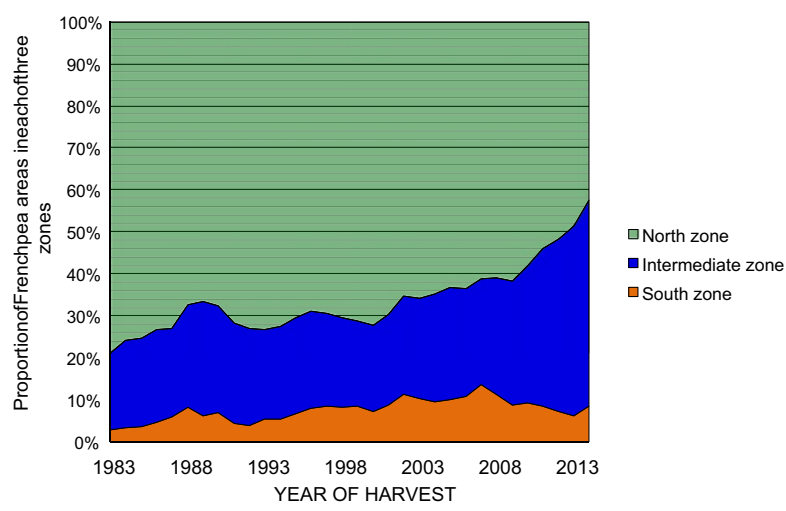

b.

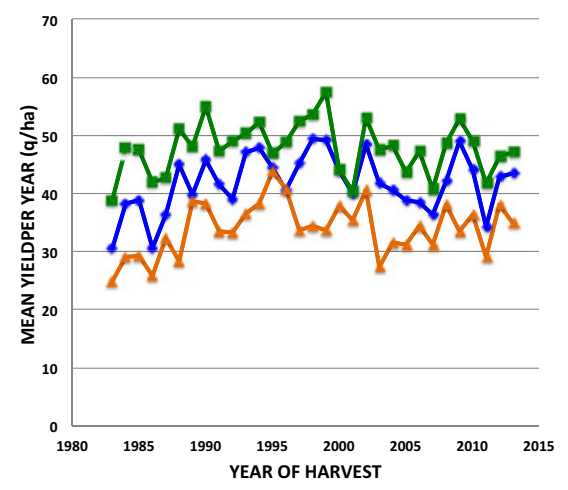

c.

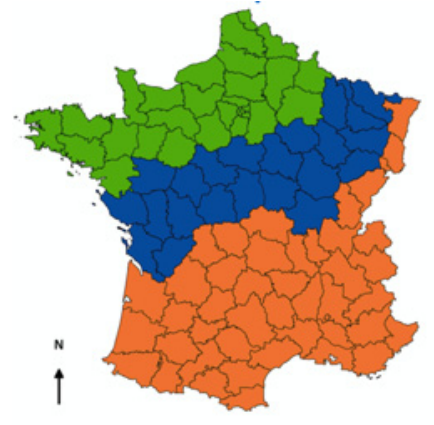

d.

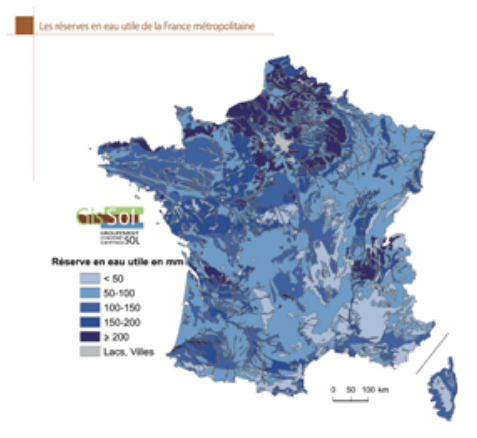

Fig. 3. Change in the distribution of pea areas (a), and mean yield (b), among three main zones (c) in France (North zone in green, intermediate zone in blue and south zone in orange) from 1983 to 2013 (from B. Carrouée, Unip, in Jeuffroy et al., 2015) and map of maximum soil water availability in France (d, from GISSOL, https://www.gissol.fr/donnees/cartes/les-reserves-en-eau-utile-de-la-france-metropolitaine-1483).

dominant (Fig. 3). From 2000 onwards, a higher proportion of pea areas were thus subjected to water stress more intense in the intermediate French zone. Moreover, in these regions where soils are characterized by low water availability, water stress may come very early and often occur during the flowering period, which has been shown to be a sensitive stage for pea (Guilioni et al., 2003). This change in the production zone was partly due to (i) numerous infestation of the traditional area by Aphanomyces euteiches (see later), (ii) the availability of other diversification crops with higher economic return, in Northern France, (iii) and increasing limiting factors affecting the dominant crops of the rotations in this intermediate zone, leading to decreasing yields of these major crops, thus leading to a diversification interest.

\subsection{The decrease of irrigated areas}

From 1996 to 2000, 17\% of the pea areas were irrigated in France, but irrigated areas dropped to $10 \%$ in 2010 (source Ministère Agriculture, DISAR). In 2015, most pea crops were managed without any supplementary water supply. This change of crop management may have had a great impact on pea yields. Irrigation allowed to adjust water supply when rainfall was not enough during the critical period of flowering. For example, in 2001, water supply on the late sowing of pea crops (April) in the center area of France enabled to reach around $60 \mathrm{q} / \mathrm{ha}$, while only $30-40 \mathrm{q} /$ ha were observed in dry situations. In 2004, a water supply in pea plots of the Center of France enabled to reach around $70 \mathrm{q} / \mathrm{ha}$, when plots without any water supply gave far lower yields: 35-45 q/ha (Biarnès, 2005). Irrigated areas were essentially located in the intermediate area (Fig. 3). The decrease of irrigation in these zones might have reinforced the impact of drought stress.

\section{Attacks of Aphanomyces euteiches}

The pathogen $A$. euteiches, located in the soil, attacks the pea roots and can prevent the crop from growing if the infestation is high. In 2000, the wet climate in April, followed by high temperatures in May, was favorable to the expression of this pathogen in contaminated plots (Quoi De Neuf, 2000). The occurrence of the disease was especially high in the eastern part of the Paris Basin, but the attacks were also very important in different areas in the north of France (Fig. 4). In 2011, a survey showed that the fungi was present in 60-90\% of the plots which have been grown with a pea within the 20 last years in Eure-et-Loir and Seine-et-Marne (Source: UNIP in Jeuffroy et al., 2015). In recent years, several wet springs enhanced strong attacks, leading to very low yields in highly infested plots (Bonilla, 2013). Winter cultivars can partly escape to this disease, because the low temperatures occurring in the early developmental stages of the crop are less favorable to the development of the disease (Moussart et al., 2016). Yield losses due to Aphanomyces are generally low on winter pea, 


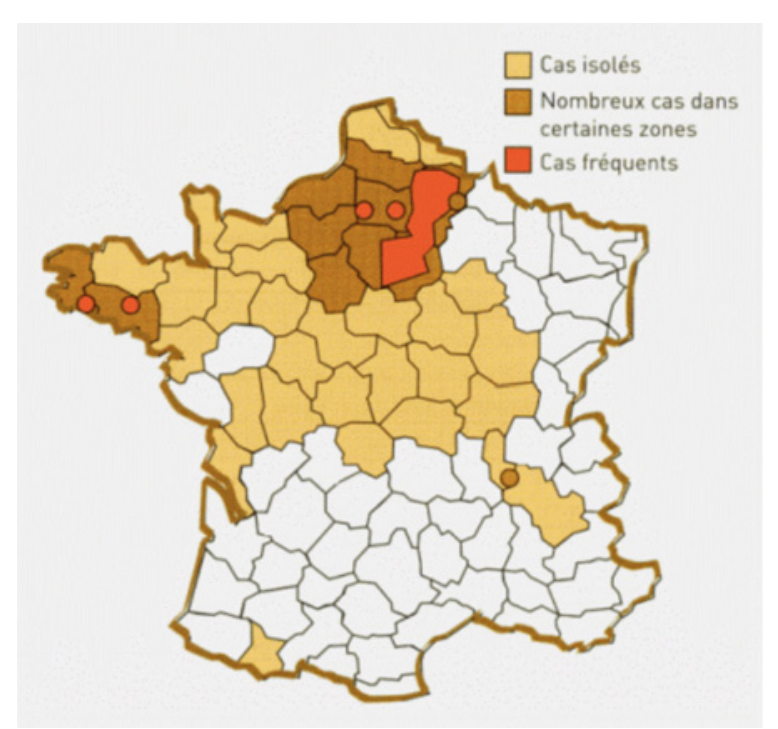

Fig. 4. Map of areas infested by A. euteiches in 2000 (source UNIPArvalis, 2001).

while they can reach more than $10 \mathrm{q} / \mathrm{ha}$ on spring pea. A biological test does exist to identify the level of infection potential in the soil. Its use could avoid sowing pea in infested fields. The trend of climate evolution, in Northern France since 30 years has shown a reduction of winter frost, a warming of winter, and a slight increase of the mean temperatures at early spring. This trend might lead to an increase of the risk for winter pea but it will depend also on the evolution of rainfall.

\subsection{Change of architecture and of yield elaboration path in varieties}

From the end of the 90s until now, breeders have greatly changed the architecture of spring pea varieties. First, they have introduced a good resistance to lodging, enabling crops to maintain high at the end of the crop cycle which facilitates harvest. Second, they decreased the 1000-seed weight, simultaneously increasing the number of nodes bearing pods. At the same time, they have reduced the number of stems per plant, and increased the size of internodes, which led to higher plants. The spring varieties cultivated at the beginning of the 90s had 1000-seed weights around $300 \mathrm{~g}$, while new varieties registered after 2000 have around 230-250 g 1000-seed weights (Schneider et al., 2015). This characteristic has changed the path of yield elaboration, balancing a reduction of the seed weight with an increase of the seed number, and of the number of reproductive nodes (Fig. 5, from Vocanson, 2006). For example, in 1998, the variety Baccara, with a large 1000seed weight (around $300 \mathrm{~g}$ ), was able to reach more than $60 \mathrm{q} /$ ha with only three-four reproductive nodes (Quoi de Neuf, 1998). Nowadays, new varieties need to develop six or seven reproductive nodes to reach the same yield. For varieties with a high 1000-seed weight and a low reproductive node number, the flowering period may be very short, whereas new varieties need more weeks of flowering. This longer duration may be interesting when the risk of climatic stress is short but unpredictable, and occurs during the period of seed formation,

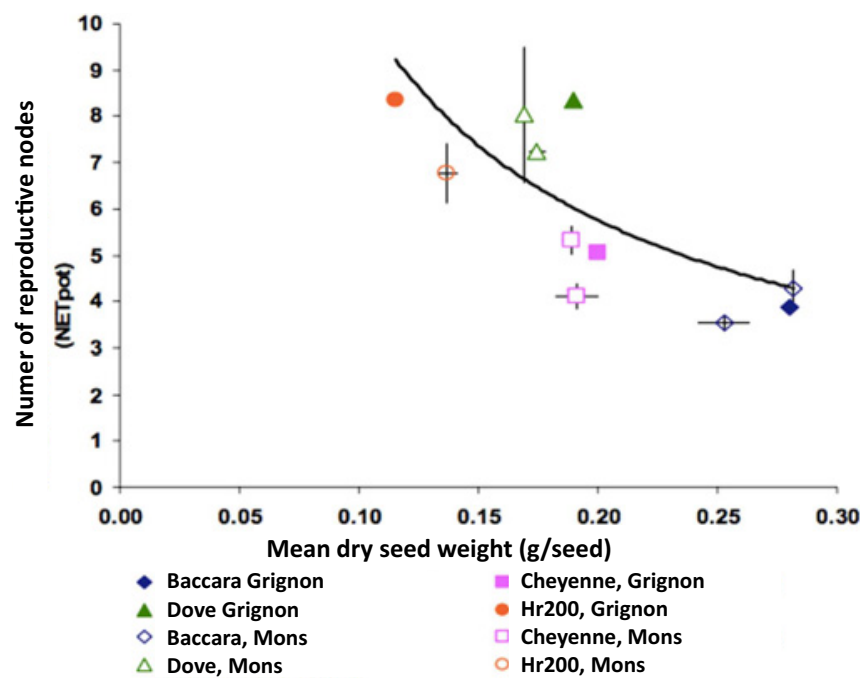

Fig. 5. Relationship between 1000 -seed weight $\left(\mathrm{P} 1 \mathrm{G}, \mathrm{g} \mathrm{gr}^{-1}\right)$ and number of reproductive nodes (NETpot), among various cultivars: data from 4 experiments in Grignon and Mons, 2002-2004 (from Vocanson, 2006).

for instance a few days with very high temperatures. In this situation, the seed abortion linked with high temperature on the nodes at their sensitive stage (Jeuffroy, 1991) may be compensated by an increased seed number on the higher nodes, when they exist! However, when the flowering duration is short, the risk of occurrence of a climatic stress during the reproductive phase is lower, but there is no possibility to compensate a stress. Another change in new pea varieties is that the beginning of flowering is later than for older ones. When flowering occurs early, the period of seed formation, determinant for yield, may escape the different climatic stresses (water, high temperatures), whereas later flowering stage allows water stress to occur during flowering time which may stop the production of new reproductive nodes, thus reducing yield. It seems difficult to have earlier spring pea type. In these situations, it is thus recommended to use winter cultivars.

\subsection{Abiotic factors reducing pea yield and their effects on the crop: knowledge and modeling}

We have seen that, due to the high sensitivity of pea to several abiotic stresses, ensuring a good pea yield is a challenge. Three main types of abiotic stresses are detrimental for pea: (i) temperature stress (high and low temperatures), (ii) water stress, and (iii) nitrogen stress. Therefore, understanding the effect of these abiotic stresses on the physiological processes of the plant is crucial. Models can be of great help to understand the interactions between these stresses, the global response of the plant to these stresses, and the effect on yield, in order to identify ways of escaping them or reducing their impacts on crop performance. Among the available crop models allowing to study the performances of a crop in a given environment and climate, the Azodyn-Pea model (Jeuffroy et al., 2012) was adapted in order to simulate pea yield in contrasted soils and climates. One of the possible uses of this 
model is to improve genotypes and adapt the choice of the cultivars to the frequency and intensity of abiotic stresses. Azodyn-Pea is a mechanistic, daily model, based on the Monteith equation to simulate growth (Monteith, 1977). It describes day-by-day biomass accumulation, nitrogen fixation and assimilation, and yield formation, according to the climate, genotype characteristics and practices. It also simulates the effects of the above mentioned abiotic stresses on these processes.

\subsubsection{Temperature stress}

The rate of pea development is a linear function based on cumulative degree days (Ney and Turc, 1993). The transition from vegetative to reproductive stages also depends on photoperiod, some cultivars, called $\mathrm{Hr}$, being highly sensitive to photoperiod, with low variability of the beginning of flowering for a large range of sowing dates (Lejeune-Hénaut et al., 2008). The effect of temperature on growth has a bell shape, with a minimum temperature under which plant grow is stopped, an optimal temperature where growth is maximum, and a maximum temperature, above which the plant cannot grow. For pea, the minimal temperature is $0^{\circ} \mathrm{C}$, the optimum one is $15.3^{\circ} \mathrm{C}$ and the maximum one is $31.3^{\circ} \mathrm{C}$ (Guilioni et al., 1997). Between these values, the plant growth is suboptimal. The plant may thus face two types of temperature stresses: high and low temperature stresses.

High temperatures mostly occur at the end of the crop cycle, during the period of seeds formation. At this critical stage, temperatures over than $25^{\circ} \mathrm{C}$ can lead to seed abortion and great yield losses (Jeuffroy et al., 1990). Guilioni et al. (2003) showed that the effect of this type of heat stress on plant growth gives a good account of its effect on seed number, due to the strong linear relationship between seed number and plant growth rate between the beginning of flowering and the final stage in seed abortion. Occurring during the seed filling period, high temperatures may affect the 1000 -seed weight. Thus, the global effect of heat stress on yield has been quantified through the cumulated maximum temperatures above $25^{\circ} \mathrm{C}$ during the whole reproductive period (between BF and FSSA), yield loss being measured as soon as this indicator exceeds $50^{\circ} \mathrm{C}$ (Jeuffroy et al., 2015). The effect of high temperatures on $\mathrm{N}$ flux being lower than on $\mathrm{C}$ fluxes, high temperatures occurring during the seed filling period tend to increase grain protein content.

Low temperatures decrease growth but do not lead to plant damages unless there is frost. Plants can better tolerate frost if their level of resistance is high, or if the hardening process of the plant is sufficient (Lecomte et al., 2003). Hardening is an active adaptation process allowing a plant to get more resistant to frost, which is enhanced by low temperatures. But, if temperatures rapidly decrease, the plant has no time enough for hardening, thus leading to tissues death, and even plant death. The level of frost resistance of a plant varies according to (i) the variety of pea, (ii) the developmental stage of the pea, and (iii) its capacity to acclimate to frost. If the length of exposition and the level of temperature exceed a threshold, the damages may be irreversible. If frost happens at the beginning of the cycle, the plant, very vulnerable, can die. A late frost, occurring after the floral initiation or during the flowering phase, can be disastrous because it can impede flowering. The model proposed on wheat (Lecomte et al., 2003) was adapted on pea and introduced in Azodyn-Pea model. Therefore, currently, only the damages during the vegetative stage are taken into account, by comparing the minimum temperature of the day to the overall resistance of the plant the same day, resulting from its variety, its stage and its acclimatization to frost. According to the level of frost, plant growth is reduced, or plant death is simulated.

\subsubsection{Water stress}

As for numerous crops, a period of water deficit affects pea growth. In the model, water deficit is calculated with the indicator called Fraction of Transpirable Soil Water (FTSW), representing the fraction of available water, compared to the maximum water content, in the layer of soil explored by roots (Lecoeur and Sinclair, 1996). A relationship linking daily FTSW and daily growth is involved in the model. In the case of legumes, water scarcity also affects the capacity of fixing atmospheric nitrogen through nodules, as these organs are sensitive to the lack of water. In Azodyn-Pea, before flowering, the fixation is prevented the day when water stress occurs, when there is no readily available water in the layer with nodule (this represents a third of the available water storage capacity). However if water conditions are better during the following day, fixation starts again as well as before the stress (Vocanson, 2006). On the contrary, after flowering, due to a competition for carbon assimilates between the filling seeds and the nodules, fixation stops and never starts again if the number of days with water stress exceeds 7 days (Salon, com. pers. in Vocanson, 2006).

\subsubsection{Nitrogen stress}

As for most crops, the capacity of the plant to transform radiation in biomass (Radiation Use efficiency) is influenced by its nitrogen nutrition status, characterized by the nitrogen nutrition index (NNI). The quantity of nitrogen absorbed by the pea each day results of the confrontation between the demand of the plant (which does not take into account the fixed nitrogen) and the nitrogen available in the soil. The total quantity of nitrogen accumulated in the plant is the combination of the absorbed and the fixed nitrogen. The capacity of pea to fix nitrogen from the atmosphere enables it to seldom face nitrogen stresses. However, a nitrogen stress can occur if a water stress lasted more than 7 days in a row after flowering stopping irreversibly fixation and if the soil was too poor in nitrogen to answer the nitrogen demand of the crop.

\subsection{Model use to predict the evolution of performances under climate change}

Climate change increases the unpredictability of both the frequency and the impact of these stresses (Stocker et al., 2013). This is a major concern as climate is an important cause of pea yield reduction over years, especially for spring peas. Today, we can incorporate climate change into the model by simulating a pea cycle in a future climate. However, the results of the simulation have limits as some consequences of climate change might not be taken into account into the model. We can model the effect of late frost or high temperature on the plant, 
how it will shift the development stages of the plant in time. However, it does not take into account that the response itself of the plant will change and therefore that new parameters might be necessary. Here is a quick overview of how the model could cope with climate change:

- Climate change will shift the development stages of the plant, which are calculated with degree-days. The increase of temperature is going to move forward stages. Then, the model will help to see if stresses are going to be amplified or if the plant is going to be able to escape them.

- One of the trends of climate change is the increase of $\mathrm{CO}_{2}$ concentrations in the atmosphere (IPCC, 2013). Currently, the $\mathrm{CO}_{2}$ concentration is not taken into account in the azodyn crop model as the model is based on the Monteith equation and not directly by modelling photosynthesis. Moreover, it is a difficult task to take into account the increase of $\mathrm{CO}_{2}$ concentration as it can have antagonists effects on the plant (Farquhar et al., 1978). According to the study of Gray et al. (2016), for soybean, the increase of concentration in $\mathrm{CO}_{2}$ will have not much impact on the yield contrary to the increase of occurrence of drought stress, which will have a great effect. Then, the rising of $\mathrm{CO}_{2}$ concentration will not counteract the effect of strong drought on photosynthesis and yield.

- Climate change will change the periodicity and intensity of frost episodes as it was shown at the Burgundy scale (Duc et al., 2010). We might see more late frost, coming during the flowering period after a very mild winter without frost. The lack of acclimation of the plant will lead to greater loss and shows the importance of adding this trait in the model and the effects of frost before and during the flowering period. A genetic variability for capacity to have quick frost acclimation during mild winters exists (Biarnès et al., 2016). The Azodyn-Pea crop model would be able to take this into account.

- Climate change is said to lead to more cloudiness and therefore a decrease solar radiation during the reproductive phase. Low solar radiation during flowering period is affecting the seed numbers, especially for winter pea which is quite sensitive (Lecomte et al., 2013).

- All these changes will have a direct effect on biotic stresses such as pests.

\subsection{Breeding and climate change: which progress can be hoped?}

The accumulation of 2 or 3 QTL for Aphanomyces partial resistance in segregating lines have been shown to slow down the development of the disease in some organs or tissues of infected plants (Lavaud et al., 2016). These recent results obtained in the current PeaMUST project are encouraging even if it is unreasonable to think that a total control against this disease might depend only on genetic resistance. Thus, more studies combining genetic resistance and cultural control should be enhanced. Similarly, against frost, the accumulation of 2 or 3 QTL of frost resistance in winter pea might allow to breed varieties with a high level of frost resistant. This type of varieties, recently created, needs to be evaluated. In the European project LEGATO, the impact of water stress and the sensitivity of the different periods of the cycle to this stress are studied. The first results show that an important and early water stress could not be compensated by the recovering of favorable water conditions, as shown on soybean (Gray et al., 2016). A better understanding of the impact of water stress and the knowledge of the genetic variability existing for this stress could allow developing varieties that could be grown in dry conditions.

\section{Conclusion}

The decrease of pea yields from 2000 to nowadays may be explained by different factors: the transfer of cultivated areas towards less favorable areas, the decrease of irrigation, and attacks by the fungi $A$. euteiches. The evolution of varieties, and especially the decrease of the 1000-seed weight could have an impact. The drought stress had a real effect on pea yields in the last 15 years. It is difficult to say if this phenomenon is going to increase or not in the future. The increase of the temperatures will have at first an effect on development stages and the sensitive period will be moved. We do not know either which will be the evolution of the rainfall distribution and the impact of disease which need wet climate to develop.

Winter cultivars not sensitive to photoperiod are available. The new varieties of this type of pea could be a solution to escape drought or high temperatures at the end of the cycle as the flowering time occurs at the end of April, 15-20 days before the flowering of the spring type. But this kind of pea could also be affected by climate conditions. The main limiting factor is frost. In January 2003, in the north of France, frost happened after some rainy days and temperatures shut down very suddenly and a great part of the winter peas was destroyed by the frost (Biarnès, 2003). In 2010, after a quite mild winter, frost occurred in March while plants had an important vegetative development. Important damages were recorded in different areas (Champagne and some part of the Center of France) (Quoi De Neuf, 2010). After these accidents caused by frost and more previous occurrence of frost, breeders have introduced resistance to frost and progress have been made on this criteria (Palleau et al., 2015). But in 2012, another episode of frost caused great damages on pea crops. The winter was very warm and pea plants had an important growth. Frost appeared suddenly on the beginning of February while plants have reached stage 6-8 leaves. The model of frost developed by Lecomte et al. (2003) on wheat and adapted to winter pea helps to understand what happened this year. The duration of the period of acclimation to frost can be changed in the model. For some varieties, a long period may explain the damages observed and at contrast, a short period for some genotypes could explain their better behavior: some genotypes need only few days with low temperatures to reach a good level of resistance. A test in controlled conditions could help to know the characteristics of each genotype to predict frost response, and adapt the cultivar management (Biarnès et al., 2016).

Furthermore, winter pea is less resistant to lodging than spring pea. For example, in 2007, rainfall in July at harvest was a great problem. Hopefully, breeders have introduced resistance to lodging in the new winter type varieties and a genetic progress on this trait was achieved with the last varieties registered (Palleau et al., 2015). 
Another limitation of the development of the winter pea is that it is more sensitive to ascochyta blight than the spring pea. In 2012 and 2016, harvesting winter pea was difficult because disease was important and the crop has fallen done to the soil. This led to great yield losses. Many recent studies on ascochyta blight showed that the limitation of the crop density and an airiness architecture could limit the development of the disease (Richard, 2010; Bénézit, 2013; Biarnès and Blosseville, 2014).

The climate change would lead to more frequent mild winters, without strong negative temperatures. Then, it is important to search genotypes which need a very short period of frost acclimation to reach a good frost resistance (Biarnès et al., 2016). Ascochyta blight would also be more frequent. It is crucial to find the optimal density to manage the crop and to increase resistance to lodging to limit the disease.

The pea crop model Azodyn-Pea can be useful to better understand the evolution of pea yield with climate change. It allows simulating the new development stages, forwarded by the increase of temperatures, and the new timing of the flowering and of seed filling periods, which are very sensitive to stresses. Moreover, the model will help to analyse if stresses are going to be amplified or if the plant is going to be able to escape them. It would be possible to evaluate the effect of temperature stresses (frost and also high temperatures at the end of the cycle), as it was already done for the Burgundy area (Duc et al., 2010). This can be very useful to analyze the possibility to grow pea in different areas in France or in other European countries in the future years. It would also be necessary to take into account the effect of ascochyta blight in the pea crop model in order to have better simulations for winter pea crop.

Finally, the registration of new varieties more resistant to different stresses (Aphanomyces, frost or water stress) derived from national or European projects will help to develop the pea crop areas despite the climate change.

\section{References}

Bénézit M. 2013. Diagnostic agronomique des facteurs limitants du rendement du pois protéagineux d'hiver et de printemps en Champagne Berrichonne. Mémoire de fin d'études ingénieur agronome spécialité Productions Végétales Durables à Montpellier SupAgro, $42 \mathrm{p}$.

Biarnès V. 2003. D'exceptionnels dégâts de gel pour un hiver atypique. Perspect Agric 293: 22-24.

Biarnès V. 2005. Variations de rendement du pois. L'impact du climat. Bulletin semences $n^{\circ} 184$ juillet-août 2005, pp. 25-27.

Biarnès V, Blosseville N. 2014. Produire du pois en Région Centre, la nécessité d'une gestion fine des parcelles. Perspect Agric 414: $37-38$.

Biarnès V, Lejeune I, Lecomte C. 2016. Pois d'hiver. La résistance au froid bientôt décryptée. Perspect Agric 436: 32-35.

Bonilla 2013. Diagnostic agronomique des facteurs limitant le rendement du pois protéagineux et identification des leviers d'action pour le producteur en Eure-et-Loire. Mémoire de fin d'études ingénieur agronome spécialité Productions Végétales Durables à Montpellier SupAgro, 36 p.

Brulebois E, Castel T, Richard Y, Château-Smith C, AmiotteSuchet P. 2015. Hydrological response to an abrupt shift in surface air temperature over France in 1987/1988. J Hydrol 531: 892-901.
Duc G, Blancard S, Hénault C, et al. 2010. Potentiels et leviers pour développer la production et l'utilisation des protéagineux dans le cadre d'une agriculture durable en Bourgogne. Innov Agron 11: 157-173.

Farquhar GD, Dubbe DR, Raschke K. 1978. Gain of the feedback loop involving carbon dioxide and stomata: theory and measurement. Plant Physiol 62 (3): 406-412.

Gray SB, Dermody O, Klein SP, et al. 2016. Intensifying drought eliminates the expected benefits of elevated carbon dioxide for soybean. Nat Plants 2: 16132.

Guilioni L, Wery J, Tardieu F. 1997. Heat Stress-induced abortion of buds and flowers in pea: is sensitivity linked to organ age or to relations between reproductive organs? Ann Bot 80 (2): 159-168.

Guilioni L, Wéry J, Lecoeur J. 2003. High temperature and water deficit may reduce seed number in field pea purely by decreasing plant growth. Funct Plant Biol 30: 1151-1164.

IPCC, 2013. Summary for policy makers.

Jeuffroy MH. 1991. Pois. Les profils de graines: interprétation et modélisation. Perspect Agric 164: 62-72.

Jeuffroy MH, Duthion C, Meynard JM, Pigeaire A. 1990. Effect of a short period of high day temperature during flowering on the seed number per pod of pea Pisum sativum L. Agronomie 2: 139-145.

Jeuffroy MH, Vocanson A, Roger-Estrade J, Meynard JM. 2012. The use of models at field and farm levels for the ex ante assessment of new pea genotypes. Eur J Agron 42: 68-78.

Jeuffroy MH, Biarnès V, Cohan JP, et al. 2015. Performances agronomiques et gestion des légumineuses dans les systèmes de productions végétales. In: Les légumineuses pour des systèmes agricoles et alimentaires durables, pp. 139-223.

Lavaud C, Baviere M, Le Roy G, et al. 2016. Single and multiple resistance QTL delay symptom appearance and slow down root colonization by Aphanomyces euteiches in pea near isogenic lines. BMC Plant Biol 16: 166.

Lecoeur J, Sinclair TR. 1996. Field Pea Transpiration and Leaf Growth in Response to Soil Water Deficits.

Lecomte C, Giraud A, Aubert V. 2003. Testing a predicting model for frost resistance of winter wheat under natural conditions. Agronomie 23 (1): 51-66.

Lecomte C, Batifoy F, Bebin T, et al. 2013. Caractérisation et optimisation du réseau d'inscription des variétés de pois d'hiver en 2007, 2008 et 2009. Innov Agron 27: 71-88.

Lejeune-Hénaut I, Hanocq E, Béthencourt L, et al. 2008. The flowering locus $\mathrm{Hr}$ colocalizes with a major QTL affecting winter frost tolerance in Pisum sativum L. Theor Appl Gen 116: 1105-1116.

Magrini M-B, Anton M, Cholez C, et al. 2016. Why are grainlegumes rarely present in cropping systems despite their environmental and nutritional benefits? Analyzing lock-in in the French agrifood system. Ecol Econ 126, 152-162.

Meynard JM, Messéan A, Charlier A, et al. 2013. Crop diversification: obstacles and levers. Study of farms and supply chains. Synopsis of the study report, $59 \mathrm{p}$.

Monteith JL. 1977. Climate and the efficiency of crop production in Britain. Philos T Roy Soc B 281: 277-294.

Moussart A, Even MN, Baranger A. 2016. Effect of pea sowing date on aphanomyces root rot development and yield losses. In: Poster presented at the 2ILS Conference in Troia, Portugal.

Ney B, Turc O. 1993. Heat-unit-based description of the reproductive development of pea. Crop Sci 33 (3): 510-514.

Palleau J-P., Biarnès V, Retailleau J-M. 2015. Variétés de pois d'hiver. Un progrès incontestable. Perspect Agric 424: 36-39.

Quoi de Neuf. 1998, 1999, 2000 and 2010. Editions Arvalis-Institut du Végétal. Paris: UNIP. 
Richard B. 2010. Analyse des interactions dynamiques entre le développement de la plante hôte, l'architecture du couvert et le développement d'une épidémie de maladie fongique aérienne : cas du pathosystème pois/ascochytose. Thèse. Rennes, France: Université Européenne de Bretagne, AgroCampus Ouest.

Schneider A, Huyghe C, Maleplate T, Labalette F, Peyronnet C, Carrouée B. 2015. Rôle des légumineuses dans l'agriculture française. In: Les légumineuses pour des systèmes agricoles et alimentaires durables, pp. 11-77.
Stocker TF, Qin D, Plattner G-K, et al. 2013. Technical Summary Climate Change 2013: The Physical Science Basis. In: Contribution of Working Group I to the Fifth Assessment Report of the Intergovernmental Panel on Climate Change, pp. 33-115. Vocanson A. 2006. Évaluation ex ante d'innovations variétales en pois d'hiver (Pisum sativum L .) : approche par modélisation au niveau de la parcelle et de l'exploitation agricole.

Voisin AS, Gastal F. 2015. In: Schneider A, Huygues Ch, eds. Les légumineuses pour des systèmes agricoles et alimentaires durables. France: QUAE Editions.

Cite this article as: Bénézit M, Biarnès V, Jeuffroy M-H. 2017. Impact of climate and diseases on pea yields: what perspectives with climate change? OCL, 2017, 24(1) D103. 